\title{
Remittances and Economic Growth in MENA Countries: The Role of Financial Development
}

\section{Imen Mohamed Sghaier}

\section{Abstract}

This paper investigates the conditional effects of remittances on economic growth in 7 MENA countries, namely, Tunisia, Morocco, Algeria, Egypt, Jordan, Lebanon, and Turkey from 2000 to 2018. Using the system generalized method of moments (GMM) in a panel data analysis, we found strong evidence of a positive relationship between remittances and economic growth. We also found that financial development acted as a complement in the remittances-growth relationship. A clearer understanding of the channels through which remittance flows will enhance economic growth in the MENA region may assist policymakers to formulate appropriate policies. In particular, a policy environment that promotes financial system development would serve to attract more remittances.

Keywords: Remittances, Financial development, Economic growth, Panel data analysis.

JEL: E21; F34; F21; J61.

\section{Introduction}

Qemittances are an important source Tof foreign capital for many developing countries. However, in policy debates there is no general agreement on the impact of remittances on economic growth. Remittances are defined as the sum of the workers' remittances, the compensation of employees, and migrant transfers. Across the world, international migration and remittances have increased significantly in recent decades. Since 2000, the migrant stock increased by $50 \%$ and in 2017, approximately 258 million people lived outside their home country. In 2019, the total remittances flows amounted to USD 714 billion, nearly $1 \%$ of the global output. According to the World Bank (2020a), remittance inflows, both in nominal terms and as a percentage of GDP, tend to be higher in low- and middle-income countries and were larger than foreign direct investments in 2019.

Remittance flows rose in the Middle East and North Africa (MENA) by $9.1 \%$ to hit $\$ 59$ billion in 2018. However, in 2020, due to the global economic slowdown caused by the novel coronavirus (COVID-19) epidemic, remittances to the MENA region are expected to fall by $8.5 \%$ to $\$ 55 \mathrm{bn}$, following the 3\% growth achieved in 2019 (World Bank,

* Assistant Professor, Department of Economics, Higher Institute of Business Administration, University of Sfax, Tunisia. 


\section{Articles}

2020b). This expected decline is a result of plummeting oil prices in the Gulf Cooperation Council (GCC) countries, considered the highest remitters in the world, leading to a sharp drop in money transfers received by the major remittance-receiving countries.

While remittances are an important source of income for the emigrants' families, they are often exposed to exchange rate risk and transaction costs. Therefore, it is not surprising that the impact of remittances on economic growth is still ambiguous and depends on whether remittances are used for consumption or for investment purposes (Kumar et al. 2018). The net amount of this income largely depends directly on the associated transaction costs of sending remittances. Also, high remittance-transfer costs not only encourage the use of informal channels, with negative implications for the financial sector, but also discourage migrants from sending higher remittance flows (Misati et al. 2019), e.g. postal services and friends or relatives travelling to the recipient countries, as a means to send remittances. The flow of remittances is also affected by the degree of competition among the transfer service providers, the legal restrictions established by monetary authorities on the financial service providers, senders and recipients, and the availability of information to the senders and recipients (Kock and Sun, 2011).

In general, remittances are largely personal transactions carried out by migrants and sent to their friends and families; they tend to be well targeted to the needs of their recipients. Their ability to reduce poverty and to promote human development is well documented and often reported as beneficial to overall development (Ratha, 2007). However, remittances, which can be similar to welfare benefits, change the economic incentive structure and therefore the economic behavior of the receivers.
Remittances and Economic Growth in MENA Countries:

The Role of Financial Development

Therefore, it is unclear if these changes will have a desirable effect on macroeconomic indicators, including economic growth. In this context, Rempel and Loddell (1978) noted that, for the most part, remittances were financing and housing expenditures, with limited dynamic effects. At the same time, most socioeconomic studies offered a strongly negative view of remittances; it was argued that remittances were used for conspicuous consumption, thus increasing dissatisfaction among non-migrants and discouraging labor supply and effort on the part of recipients, thus increasing dependency and delaying rural development and change.

It is widely accepted that a welldeveloped financial system is considered as one of the key foundations on which sustained economic development can be built (Demirguc-Kunt, 2006). Indeed, as Levine's (2005) comprehensive review of finance and development makes it clear, financial systems have five closely interrelated roles: to produce information ex ante about possible investments opportunities and allocate capital to them; to monitor investments and exert corporate governance after providing finance; to facilitate the trading, diversification and management of risk; to mobilize and pool savings; and to facilitate the exchange of goods and services. The financial sector is well placed to mobilize funds like remittances to productive investments and income/ employment generating activities (Mundaca, 2009; Nyamongo et al. 2012; Akobeng, 2016; Adekunle et al. 2020). These arguments above support the fact that financial development is an important channel through which remittances influence economic growth.

The relationship between remittances, financial development and economic growth has been of interest to migration scholars for quite some time. Whenever it was indicated that remittances have increased in or perceived 


\section{Articles}

to have an impact on a particular country or region, subsequent studies have followed in conjunction with financial development. The majority of the existing studies showed that remittances have pro-growth effects in the presence of a developed financial system (Aggarwal, et al. 2011; Ramirez, 2013; Kumar et al. 2018).

Our motivation is to examine and empirically evaluate the significance of the relationship between remittances and economic growth through the financial development channel in 7 MENA countries, namely, Tunisia, Morocco, Algeria, Egypt, Jordan, Lebanon and Turkey over the 2000-2018 period. ${ }^{1}$ The inclusion of this variable in the model can be motivated by the fact that remittances alone would not be strong enough to promote economic growth. In this context, many empirical studies have investigated the key channels of how remittances affect economic growth. Indeed, this study examines whether financial development can be a positive moderator for the impact of remittances on economic growth from the perspective that financial development stands for the absorptive capacity of host economies, as in the spirit of endogenous growth theories (Tang and Zhang, 2016).

This paper contributes to the existing literature in two ways. First, as pointed out in the empirical literature, that impact of remittances on growth may be conditioned by other factors, particularly financial development; the present study examines this issue. With a poorly developed credit market, households may use remittances as an alternative source of finance to fund activities (Bettin and Zazzaro, 2012). However, it is possible that a well-functioning financial market helps to lower the monetary and non- monetary costs of channeling remittances into the formal sector, thereby enabling more growth-enhancing projects. So far, only a few studies (e.g. Giuliano and Ruiz-Arranz, 2009; El Hamma, 20018) have examined this issue, and even fewer in the context of MENA region. Second, in terms of policy implications, the results of this research will guide policy makers in designing policies aimed at better directing external capital, such as remittances, towards sectors with the highest effect on economic growth. Our regressions show that a solid financial system complements the positive effect of remittances on economic growth.

The remainder of the article is structured as follows. Section 2 reviews some of the voluminous extant literature. Section 3 describes the data and empirical methodology. The empirical results are presented in Section 4. The final section draws conclusions based on the results.

\section{Literature Review}

\subsection{Remittances and economic growth}

Many empirical studies focus on the impact of remittance inflows on the living standards of recipient households. In this context, Abdih et al. (2012) showed that remittances help lift huge numbers of people out of poverty by enabling them to consume more than they could otherwise. They also tend to help the recipients maintain a higher level of consumption during economic difficulty (Chami et al. 2012). Recent studies report that these inflows allow households to work less, take on risky projects they would avoid if they did not receive this additional source of income, or invest in the education and healthcare of the household. In other words, remittances are a benefit for households.

\footnotetext{
1 The choice of the MENA countries is motivated by the fact that the relationship between remittances and economic growth has been poorly examined in the literature about these countries, and these are important sources of expatriate workers.
} 


\section{Articles}

Others focus on the short-run macroeconomic impact of remittances, typically finding a positive relationship with aggregate income, investments and employment (León-Ledesma and Piracha, 2001; Le, 2011; Dzansi, 2013).

The effects of remittance inflows on economic growth depend on how such financial resources are used, whether directly by recipients or indirectly, through the intermediation of financial institutions, by other people in the country. If they can be channeled into productive investment, or if they enhance the creditworthiness of recipients and their access to external financial resources, the impact on economic growth is positive. If, however, the usage of remittances are for increasing consumption and expenditures on housing, land and other forms of second-hand non-financial assets, the association with the economic growth is very weak (Coon, 2014).

Similarly if remittances are used to finance current consumption, this may lead to faster inflation and an increase in the relative price of non-tradable items. The resulting appreciation in the real exchange rate may then discourage exports and have a negative effect on economic growth (Chami et al. 2008). A negative effect could also be exerted if remittances encourage individuals to substitute leisure for work (Chami et al. 2003). In this context, Salvador and Ducanes (2019) examined the effects of remittances on the economic growth of the manufacturing sector in low and lower middle income economies. They concluded that remittances can adversely influence long-run manufacturing growth via a "Dutch Disease" channel. Indeed, remittances, which are deposited in local banks, increase both the economy's liquidity and credit supply and demand. If excess demand for money ensues, there is upward pressure on the interest rate. Satisfying the uncovered interest parity condition implies an appreciation of the domestic currency, which
Remittances and Economic Growth in MENA Countries:

The Role of Financial Development

renders tradable items, mostly comprising manufacturing goods, less competitive in the long run.

In a study covering up to 113 countries over the 1970-1998 period, Chami et al. (2005) found a negative link between remittances and economic growth. They noted that remittances are intended for consumption and do not act as a source of capital for economic growth. The fact that remittances are initially spent on consumption, housing, and land, and are not used for direct productive investment is often taken as a loss of resources for promoting economic growth. Some other studies that found a negative or no relation between remittances and economic growth include Barajas et al. (2009) and Gupta (2005). Similarly, a study by the IMF (International Monetary Fund, 2005), covering 101 countries over the 19702003 period, found no significant relationship between remittances sent by migrants and growth or between remittances and variables such as education or investment rates. On the other hand, Ekanayake and Mihalis (2008) observed that remittances inflow significantly promotes economic growth in developing countries covering Asia, Africa, and Latin America and the Caribbean over the 19802006 period.

Giuliano and Ruiz-Arranz (2009) analyzed the economic growth of a set of 73 developing countries in the $1975-2020$ period and showed that, on average, remittances have no significant influence on economic growth. Similarly, Jongwanich (2007) examined the effects of migrant remittances on economic growth for a panel of 17 countries in the Asia and Pacific region over the 1993-2003 period. They found a statistically insignificant coefficient associated with remittances in the economic growth equation. Lim and Simmons (2015) examined the economic importance of remittances flows to 13 countries in the 


\section{Articles}

Caribbean Community and Common Market, using the data covering the 1975-2010 period. They found no long-run association between remittances and economic growth in the region. They also concluded that the remittances flows to the Caribbean are mostly used to finance consumption needs rather than invest in growth-enhancing projects.

On the other hand, Fayissa and Nsiah (2010) studied the impact of remittances on economic growth using panel data from 36 African countries spanning 1980-2004. They found that remittances positively impact economic growth by providing an alternative way to finance investment and helping to overcome liquidity constraints. In addition, Yaseen (2012) observed the impacts of remittances on economic growth for the panel data of nine MENA countries (Algeria, Egypt, Jordan, Libya, Morocco, Oman, Syria, Lebanon and Tunisia) over the 2000-2010 period, and showed a significant increase in remittance inflows to promote economic growth in the sampled countries. Moreover, using the system GMM estimator, Ben Mim and Ben Ali (2012) showed that remittances can enhance economic growth by encouraging human capital accumulation in 15 MENA countries over the 1980-2009 period. Similar results are reported by Nsiah and Fayissa (2013), who found a positive relationship between economic growth and remittances, using a panel of 64 different countries in Africa, Asia, and Latin America-Caribbean (LAC) over the 1987-2007 period.

Using a dynamic panel estimation of 33 top remittance-recipient developing countries over the 1979-2011 period, Chowdhury (2016) confirmed that remittances exert a positive influence on economic growth in the sampled countries. Meyer and Shera (2017) examined the economic growth effect of remittances in 6 countries, Bulgaria, Albania, Moldova, Macedonia, Romania, and Bosnia
Herzegovina over the 1999-2013 period and noted that remittances exert a positive effect on economic growth. Furthermore, in a study covering 4 North African countries over the 1980-2012 period, Zghidi et al. (2018) found that remittances tend to have a stronger influence on economic growth in countries with higher economic freedom. More recently, Ekanayake and Moslares (2020) analyzed the effects of remittances on economic growth and poverty in 21 LAC for the 1980-2018 period. They concluded that remittances have a positive effect on economic growth in the majority of the countries studied.

\subsection{Interactions between remittances and finance in promoting growth}

Current discussions on the relation between remittances and financial development are based on the question whether these two variables are substitutes or complements. On the one hand, the complementarity hypothesis claims that remittances and financial development foster one another. While a higher degree of financial development allows migrants to send money home faster, more safely and above all more cheaply, large amounts of remittances stimulate the interest of financial institutions and public authorities, bringing about higher levels of competition between financial intermediaries, as well as institutional reforms aiming at channeling remittances towards productive investment. In addition, a more developed financial system in the home country should entail lower costs of transferring money (Freund and Spatafora, 2008). Finally, in countries where the banking system is well developed, remittances may complement bank credit or may act as collateral to gain access to it. Migrants might then be encouraged to transfer money to their families in the hope that it will not be wasted in unproductive consumption (Chami et al. 2005). On the other hand, a substitution mechanism could also be at work: when 


\section{Articles}

domestic credit markets are poorly developed, a large number of households with potentially productive investment projects have no access to external finance or may borrow only at higher interest rates. In this case, remittances may be used as an alternative source of finance allowing recipient households to fund productive activities.

The empirical literature on the relationship between remittances and financial development tests two hypotheses; the substitutability hypothesis on the one hand, and the complementarity hypothesis, on the other. For example, Giuliano and Ruiz-Arranz (2009) concluded that remittances have a positive and significant effect on economic growth and financial development facilitates such growth (especially in countries with less developed financial systems), but have a negative impact in countries with a more developed financial system in a panel of 100 developing countries over the 1975-2002 period. Substitutability between these two variables is also evident in Barajas et al. (2009). This argument is supported by Ramirez and Sharma (2009) who argued remittances to be growth enhancing in a panel of 23 LAC countries over the 1990-2005 period. Both of these studies indicate that in areas with low levels of financial development remittances act as substitutes for financial markets.

In contrast, Mundaca (2009) examined the impact of remittances on economic growth in the context of 25 Latin America and the Caribbean nations during 1970-2002 and found that while remittances alone can have a positive and significant impact on economic growth, the impact is even greater when the country has good financial intermediation. Bettin and Zazzaro (2012) studied the role of remittances in promoting growth in 66 developing countries during the 1970-2005 period, controlling for financial development and governance institutions. Their study
Remittances and Economic Growth in MENA Countries:

The Role of Financial Development

showed that remittances can enhance economic growth only in countries with a properly functioning banking sector and wellestablished governance institutions.

El Hamma (2018) investigated the conditional effects of remittances on economic growth in 14 MENA countries over the 1982-2016 period. He revealed a complementary relationship between financial development and remittances to ensure economic growth. He also showed that remittances promote economic growth in countries with a developed financial system and a strong institutional environment. On a panel of 54 developing countries over the 1970-2010 period, Sobiech (2019) confirmed that the more financially developed a country is, the smaller the impact of remittances on economic growth. Remittances can promote growth, but the effect is significant only at low levels of financial development. This is in line with previous research, which found substitutability effects of remittances and financial development.

Olayungbo and Quadri (2019) investigated the relationship among remittances, financial development and economic growth in a panel of 20 Sub-Saharan African (SSA) countries over the 2000-2015 period. They concluded that remittances and financial development are positively associated with economic growth. The interactive term confirmed that financial development acted as a substitute in the remittances-growth link. Similarly, Jongwanich and Kohpaiboon (2019) examined the impact of remittances on economic growth in developing Asian and Pacific countries, using data for the period 1993-2013, controlling for financial development. Their study highlighted some degree of substitutability between remittances and financial development. More recently, Cao and Kang (2020) studied the effect of remittances and financial development on the 


\section{Articles}

economic growth of 29 economic transition countries over the 2000-2015 period. They found that there is a positive link between remittances and economic growth. They also confirmed that remittances and the level of financial development have a substitute relationship in promoting economic growth.

On the contrary, the complementarity relationship between remittances and financial development in improving economic growth is found by Mundaca (2009). Using the panel data of 25 LAC countries over the 19702002 period, she found that while remittances alone can have a positive and significant impact on long-run growth, the impact is even greater when the country has good financial intermediation. Similarly, Aggarwal et al. (2011) considered one hundred and nine countries over the $1975-2007$ period and examined the link between remittances and financial development. They found that a greater financially developed system might lead to larger measured remittances, since financial development helps increase the propensity to remit via official channels.

Nyamongoet al. (2012) examined the role of remittances and financial development on economic growth in a panel of 36 countries in Africa over the 1990-2009 period. They concluded that remittances appear to be working as a complement to financial development. Bettin and Zazzaro (2012) examined the role of remittances in promoting growth in 66 developing countries during the 1970-2005 period, controlling for financial development and governance institutions. Their study showed that remittances can promote growth only in countries with a properly functioning banking sector and well-established governance institutions. Ramirez (2013) estimated the impact of remittances and financial variables on the economic growth of selected high- and lowincome countries in LAC over the 1990-2007 period. They showed that a positive effect of remittances in both income groups were stronger in the presence of credit, although credit and the degree of economic freedom were positive and significant only in the upper income countries.

Akobeng (2016) evaluated the effectiveness of remittances in 41 SSA countries over the 1981-2010 period. He found that a well-developed financial infrastructure that improves the accessibility of migrants and their families in the home country to formal financial institutions is a panacea for increasing remittance inflows for poverty reduction. Fromentin (2018) examined the relationship between remittances and financial sector development in a panel of 36 LAC countries over the 1970-2013 period. He found a positive, significant, and robust bidirectional link between remittances and financial development for the sampled countries.

Kadozi (2019) examined the impact of remittance inflows on economic growth in 45 SSA countries over the 1980-2014 period. $\mathrm{He}$ found that remittance-growth impact is positively and statistically significantly conditioned by the country's level of development, financial development, and education in the region. More recently, Adekunle et al. (2020) examined the structural linkages between remittances and financial system development in 53 African countries over the 1986-2017 period. They found a positive long-run relationship between remittances and financial development. They also argued that, while attracting migrants' transfers who can have significant short-run poverty-alleviating advantages, in the long run, it might be more beneficial for African governments to promote financial system development using alternative financial development strategies. This paper seeks to extend this literature by examining the 


\section{Articles}

conditional effect of remittances on economic growth. Specifically, we investigate the interaction between remittances and financial development to assess the conditions in which remittances can improve economic growth in MENA countries.

\section{Data and Empirical Methodology}

\subsection{Data}

This paper considers a sample of 7 MENA countries namely, Tunisia, Morocco, Algeria, Egypt, Jordan, Lebanon, and Turkey. The choice of the selected countries for this study is primarily dictated by the availability of reliable data over the sample period. The panel covers the 2000-2018 period. The dependent variable is economic growth, measured as the growth rate of real GDP per capita at 2010 USD prices. The main variable of interest (remittances) and the other control variables are obtained from the World Development Indicators database (World Bank, 2020).

Remittances are generally defined as the sum of three items in the IMF's Balance of Payment Statistics: the compensation of employees (part of the income component of the current account), workers' remittances (part of current transfers in the current account) and migrants' transfers (part of the capital account). This also reveals the standard definition in the World Development Indicators database of the World Bank.

We include a country's level of financial development as another regressor, because it helps saving and investment decisions. Financial markets also allow for risk diversification through the negotiation of financial instruments that facilitate identification of profitable investment projects and mobilize savings on them. Financial development (FD) is defined as the ratio of credit provided by the banking sector to GDP. This indicator measures how much intermediation is
Remittances and Economic Growth in MENA Countries:

The Role of Financial Development

performed by the banking system, including lending to the public and the private sectors. Calderon and Liu (2003) found that a higher ratio of credit provided by the banking sector to the GDP shows more financial services and therefore, more efficient financial intermediation and greater contributions to overall economic growth.

The hypothesis that remittances and other economic and institutional variables affect economic growth is tested by estimating the dynamic panel data model for GDP per capita growth over the 2000-2018 period. Specifically we consider the most used variables in the empirical economic growth theory defined as follows:

- Initial GDP per capita (log): log of real GDP per capita. The link between initial per capita GDP and growth rates is a vital implication of the neoclassical growth theory; that is, an economy's growth performance depends on its initial position. This literature indicated that, ceteris paribus, backward countries with a low capital-output ratio may grow faster than rich countries due to the diminishing return to factors of production. A negative coefficient is expected;

- Private investment ( $\%$ GDP) is viewed as a direct proxy of contribution to capital accumulation, as well as an indicator of efforts to develop basic economic infrastructure. It is defined as the ratio of gross fixed capital formation to GDP. A positive coefficient is estimated, as greater investment shares have been shown to be positively associated with economic growth (Mankiw et al. 1992);

- Human capital is a key determinant of technology adoption as permitted by trade openness. The effect of human capital is measured by primary school enrollment. Greater enrollment ratios lead to greater human capital, which should 


\section{Articles}

be positively associated with economic growth (Benhabib and Spiegel, 2005). A positive coefficient is expected.

In order to account for the effects of macroeconomic stability on economic growth, two additional variables will be added to the model':

- Inflation rate is measured as the annual percentage change in the consumption price index. ${ }^{3}$ A negative coefficient is expected, as high inflation has been shown to affect economic growth negatively (Elder, 2004);

- Government spending defined as the ratio of government consumption to GDP. Excessive government spending is expected to crowd out investment in the private sector and be harmful to economic growth (Nguyen and Trinh, 2018). Thus, a negative coefficient is expected.

The extended model will also include the following institutional variable4:

- The economic freedom of the World index from the Fraser Institute is used to measure the freedom of economic activities in a country. Higher indices are related to smaller governments (Area 1), stronger legal structure and security of property rights (Area 2), access to sound money (Area 3), greater freedom to trade internationally (Area 4), and more flexible regulations of credit, labor, and business (Area 5). The comprehensive area scores are all on a scale from zero to 10 , with zero being the least and 10 being the most free. The greater the economic freedom, the more it enhances economic growth (Azman-Saini et al. 2010). Thus, a positive coefficient is expected. The data are obtained from Gwartney et al. (2020).

\subsection{Empirical methodology}

The purpose of our empirical analysis is to examine if financial development plays an important role in influencing the effects of remittances on economic growth in the MENA region. To this end, we employ a specification that is broadly similar to Bettin and Zazzaro (2012). We consider the following model:

$$
\begin{aligned}
y_{i, t}= & \alpha y_{i, t-1}+\beta_{1} R_{E M_{i, t}}+\beta_{2} F D_{i, t}+ \\
& \beta_{3} X_{i, t}+\mu_{t}+\eta_{i}+\varepsilon_{i, t}
\end{aligned}
$$

Eq. (1) can also be alternatively written with the growth rate as a dependent variable as:

$$
\begin{array}{r}
\text { Growth }_{i, t}=y_{i, t}-y_{i, t-1}=(\alpha-1) y_{i, t-1}+ \\
\beta_{1} R E M_{i, t}+\beta_{2} F D_{i, t}+\beta_{3} X_{i, t}+ \\
\mu_{t}+\eta_{i}+\varepsilon_{i, t}
\end{array}
$$

The subscript " $t$ " represents the periods, whereas $i$ represents the country, $y$ is the logarithm of the real GDP per capita, REM is equal to remittances over GDP, FD is the financial development variable and $X$ is the matrix of control variables, $\mu_{t}$ is a time specific effect, $\eta_{i}$ is an unobserved countryspecific fixed effect and $\varepsilon_{i, t}$ is the error term. Eq. (2) forms the basis for our estimation. $(\alpha-1)$ is the convergence coefficient.

While REM has the potential to affect economic activity through a host of channels, in a second set of regressions, we examine one specific link between REM and economic growth, specifically the one working through FD. The hypothesis we would like to test is

\footnotetext{
${ }^{2}$ Following Levine et al. (2000), we include the inflation rate and the government size to proxy for macroeconomic stability in a growth regression.

${ }^{3}$ In order to solve the problem of heteroscedasticity resulting from the high variability of inflation rates, Inflation was defined as $\log (1+\ln / / 100)$.

4 There is extensive literature that considers the role of institutions on economic growth. See Acemoglu et al. (2001), Glaeser et al. (2004) and De Haan (2007), among others.
} 


\section{Articles}

whether the level of FD in the host country affects REM on economic growth. To this end, we add an interaction term constructed as the product of REM and the FD (i.e., REM*FD) to Eq. (2) as an additional explanatory variable, apart from the standard variables used in the economic growth equation. To ensure that the interaction term does not proxy for REM or the level of FD, both of the latter variables were included in the regression independently. A negative coefficient indicates that remittances are more effective in boosting growth in countries with poorly developed financial systems. In other words, a negative interaction provides evidence of substitutability between remittances and financial development. On the other hand, a positive interaction would imply that the growth effects of remittances are enhanced in countries with betterdeveloped financial systems. This implies complementarity of remittances and financial development.

We estimated equation (2) with an interaction term between remittances and the financial development variable as follows:

$$
\begin{array}{r}
\text { Growth }_{i, t}=(\alpha-1) y_{i, t-1}+\beta_{1} \text { REM }_{i, t}+ \\
\beta_{2} F D_{i, t}+\beta_{3}\left(R E M_{i, t} . F D_{i, t}\right)+ \\
\beta_{4} X_{i, t}+\mu_{t}+\eta_{i}+\varepsilon_{i, t}
\end{array}
$$

This paper applies the GMM panel estimator developed by Arellano and Bond (1991), Arellano and Bover (1995), and Blundell and Bond (1998). Overall, there are several advantages in the System GMM estimator since it controls for time-invariant country specific effects; deals with the endogeneity problem of lagged dependent variable; permits a certain degree of endogeneity in the other regressors, and optimally combines information on cross-country variation in levels with that on within-country variation in changes.

We analyze this endogeneity by using a two-step system GMM for the estimation
Remittances and Economic Growth in MENA Countries:

The Role of Financial Development

of dynamic unbalanced panel data. In the case of a strong endogeneity, the twostage least squares (2SLS) method can be used. However, Lin and Lee (2010) showed that estimations provided by 2SLS are often weak in the presence of heteroscedasticity. In this context, the GMM is more effective (Lee, 2007). Precisely, system GMM estimators are well-known to treat situations in which explanatory variables are not strictly exogenous. Therefore, the traditional fixed effect estimator is incoherent because the mean of the lagged dependent variable is correlated with the idiosyncratic error term. As mentioned by Nickell (1981), this problem becomes particularly interesting in dynamic panel data models with relatively few time periods. A particular solution has been established by Arellano and Bond (1991), Arellano and Bover (1995) and extended by Blundell and Bond (1998), who argued that the system GMM estimators will reduce the bias associated with the fixed effects in short panels and resolve the problem of endogeneity in dynamic panel data. It is worth mentioning that a two-step system GMM estimator is asymptotically more efficient than a one-step estimator (based on a sub-optimal weighting matrix). However, the former might produce a bias of uncorrected standard errors when the instrument count is high, implying that the number of instruments is less than the number of the cross-sections, which was emphasized by Roodman (2006).

Following suggestions by Roodman (2006), the validity of the instruments implemented in GMM is generally verified by using the Hansen and the Arellano-Bond's $A R(2)$ tests for the estimation of autocorrelation. It is also worth noting that the asymptotic standard errors of the two-step GMM estimators can be reduced through decomposition into small samples (Windmeijer, 2005). As noted in Windmeijer (2005), a Monte Carlo simulation shows that 


\section{Articles}

the conventional asymptotic variance estimate of two-step GMM estimators is a good estimate of the variance of GMM estimators using all the true values of the parameters to calculate the efficient weight matrix. In other words, the estimated corrected variance of the two-step GMM estimators achieves more accurate inference results. The two-step system GMM estimators are a good estimation tested in a lot of existing research (Baltagi, 2008) and that is why we used it in this study.

\section{Empirical results}

The empirical results are presented in Table 1. Column (1) reports a preliminary analysis of the effects of remittances and financial development on economic growth. Column (2) presents the coefficient estimates obtained from the baseline specification, which used an interaction term constructed as a product of remittances and financial development.

Table 1. The growth effect of remittances and financial development

\begin{tabular}{|c|c|c|}
\hline Variable & (1) & (2) \\
\hline Initial GDP per capita & $\begin{array}{c}-0.410^{\star} \\
(0.058)\end{array}$ & $\begin{array}{r}-0.631^{\star *} \\
(0.029)\end{array}$ \\
\hline Remittances & $\begin{array}{l}0.011^{\star \star} \\
(0.034)\end{array}$ & $\begin{array}{l}0.015^{\star} \\
(0.021)\end{array}$ \\
\hline Financial Development & $\begin{array}{r}0.047^{\star *} \\
(0.023) \\
\end{array}$ & $\begin{array}{r}0.045^{\star *} \\
(0.031)\end{array}$ \\
\hline Remittances*Financial Development & - & $\begin{array}{r}0.002^{\star \star} \\
(0.027)\end{array}$ \\
\hline Private Investment & $\begin{array}{r}0.044^{*} \\
(0.0756) \\
\end{array}$ & $\begin{array}{r}0.013^{\star \star *} \\
(0.000) \\
\end{array}$ \\
\hline Human capital & $\begin{array}{r}0.012^{\star *} \\
(0.042) \\
\end{array}$ & $\begin{array}{r}0.014^{* * *} \\
(0.000) \\
\end{array}$ \\
\hline Inflation & $\begin{array}{r}-0.025^{\star} \\
(0.085)\end{array}$ & $\begin{array}{c}-0.023^{*} \\
(0.089)\end{array}$ \\
\hline Government Spending & $\begin{array}{l}-0.022 \\
(0.315) \\
\end{array}$ & $\begin{array}{l}-0.031 \\
(0.255) \\
\end{array}$ \\
\hline Index of Economic Freedom & $\begin{array}{r}0.01^{*} \\
(0.058) \\
\end{array}$ & $\begin{array}{l}0.012^{\star} \\
(0.073) \\
\end{array}$ \\
\hline Constant & $\begin{array}{r}-0.181^{* \star *} \\
(0.000) \\
\end{array}$ & $\begin{array}{r}-0.068^{\star \star \star *} \\
(0.000)\end{array}$ \\
\hline R-Squared & 0.74 & 0.75 \\
\hline AR(2) test ( $p$-value) & 0.64 & 0.68 \\
\hline Sargan test (p-value) & 0.742 & 0.732 \\
\hline
\end{tabular}

Notes: The dependent variable is the growth rate of real GDP per capita. System GMM estimations in dynamic panel data models. Sample period 2000-2018. AR(2) is a test of second order residual serial correlation. J-test is the Hansen over identification test. p-values are in parentheses. ${ }^{*},{ }^{* *}$, and ${ }^{* * *}$ indicate statistical significance at $10 \%, 5 \%$ and $1 \%$ levels, respectively.

Further evidence of the importance of remittances to economic growth are shown in Table 1, where the financial development indicator is introduced into the model, and it is found that the estimated coefficient is largely positive and significant at the conventional levels of testing. The results suggest that the main variable of interest, migrant remittances to GDP are positive and statistically significant in all the columns, suggesting that remittances contribute significantly to economic growth 


\section{Articles}

in the MENA region. However, the impact is more pronounced when the financial development variable is included. Column (1), for example, suggests that a $1 \%$ increase in remittances leads to a $0.011 \%$ increase in the growth rate. A 1\% increase of migrant remittances leads to a $0.015 \%$ increase of economic growth in column (2). This conclusion is also consistent with the results of many studies, such as Nyamongo (2012) and Lim and Simmons (2015).

The role of financial development is shown in Table 1. In particular, we explore whether the financial development of the recipient country influences the specific uses given to remittances and their capacity to influence growth. To this end, we estimate Eq. (2), which allows the impact of remittances on economic growth to vary across level of financial development in the recipient country. The financial development coefficient carries a positive sign and is statistically significant at conventional levels, confirming a longrun positive relationship between financial development and economic growth. This positive impact is in line with much of the empirical finance and economic literature (see Levine, 2005, for a broad survey). Additionally, the estimated regression passed both specification tests. The null hypothesis of no second-order serial correlation cannot be rejected at the $5 \%$ level. The regression is not plagued by a simultaneity bias as the orthogonality conditions cannot be rejected at the $5 \%$ level, as indicated by the Hansen test. This suggests that the equation is adequately specified and the instruments employed in the analysis are valid.

Column (2) displays the regression results based on interaction specification using an interaction term between remittances and the financial development. In this specification, we relied on the interaction
Remittances and Economic Growth in MENA Countries:

The Role of Financial Development

term to establish the contingency. If the term is positive and significant, this would imply that the effect of remittances on economic growth increases with financial development. The first thing to note is that the sign of the coefficient of the interaction term between remittances and the financial development is positive, implying that remittances and the financial development act as complements. This suggests that the growth impact of remittances is enhanced in the presence of a better-developed financial system. Indeed, enhanced financial development will result in more remittances being channeled through the official financial system. This will provide more liquidity to the financial system and thereby ensure that more and more credit becomes available. The provision of more credit to the productive sectors of the economy will stimulate economic growth. This finding supports the complementarity hypothesis and corroborates the findings by Bettin and Zazzaro (2012); Nyamongo (2012) and Kadozi (2019). However, our findings suggest that public authorities in today's MENA countries should try to maximize the impact of remittances by identifying policies aiming to promote financial development, that is, policies that facilitate the access to financial services, that provide information about the remittance market, and that ensure greater transparency in the financial system. Insofar as financial development has positive impacts on economic growth, such policies should also help to accelerate the process of catching-up in the real income of emigration countries.

Most of the results regarding the other explanatory variables are also in line with the expectations. To test the conditional convergence hypothesis in the sample countries, we use the natural log of initial GDP per capita as an explanatory variable. As shown in most of the columns in Table 


\section{Articles}

1, the coefficient of initial GDP per capita is both negative and statistically significant, which confirms the convergence hypothesis for the sample countries. This is consistent with Barro and Sala-i-Martin (1997). Private investment and human capital have positive and statistically significant coefficients, indicating that greater private investment and more highly-educated work force increase economic growth. Regarding macroeconomic stability, inflation and government spending have the expected signs, but only the first is statistically significant. The index of economic freedom is included in the model in order to explain the impact of institutional quality on economic growth. It takes a positive sign and is statistically significant at conventional levels, considering that economic growth is stronger when economic freedom is high because it makes investment more productive. This finding is consistent with the survey conducted by Azman-Saini et al. (2010) who concluded that economic freedom is an important factor for economic growth.

\section{Conclusions}

This paper examined the impact of remittances on economic growth. More specifically, this paper sought to analyze whether the impact of remittances on economic growth is conditioned on financial development. A GMM panel data model was used to examine the link between remittances, financial development and economic growth on a panel of 7 MENA countries, over the 2000-2018 period, where both remittances and financial development have a significant and positive impact on economic growth.

To explore how the level of financial development of the recipient country affects the impact of remittances on economic growth, we introduce an interaction term between remittances and the financial development level. The result finds some degree of complementarity between remittances and financial development; that is, remittances potentially help to promote economic growth in countries where the financial system is developed.

From a policy perspective, it is important for policymakers to develop and implement policies to encourage remittance inflows through official channels. The role of public authorities could be to shape the financial environment to leverage these flows by improving financial development. The MENA countries must implement better investment policies that will help to attract more investment from their emigrants, especially in countries with low ratios of remittances to GDP.

\section{References}

Abdih, Y., Barajas, A., Chami, R., and Ebeke, C., (2012). "Remittances channel and fiscal impact in the Middle East, North Africa, and Central Asia," IMF Working Paper, n'104.

Acemoglu, D., Johnson, S., and Robinson, J., (2001). "The colonial origins of comparative development: An empirical investigation", American Economic Review, 91, 1369-1401.

Adekunle, I.A., Tella, S.A., Subair, K., and Adegboyega, S.B., (2020). "Remittances and financial development in Africa", Journal of Public Affairs, e2545, 1-11.

Aggarwal, R., Demirguç-Kunt, A., and Peria, M. S., (2011). "Do remittances promote financial development?", Journal of Development Economics, 96, 255-264.

Akobeng, E., (2016). "Out of inequality and poverty: Evidence for the effectiveness of remittances in Sub-Saharan Africa", The Quarterly Review of Economics and Finance, 60, 207-223.

Arellano, M., and Bond, S., (1991). "Some tests of specification for panel data: Monte Carlo evidence and an application to 


\section{Articles}

employment equations", Review of Economic Studies, 58(2), 277-297.

Arellano, M., and Bover, O., (1995). "Another look at the instrumental variable estimation of error-component models", Journal of Econometrics, 68(1), 29-51.

Azman-Saini, W.N.W., Law, S.H., and Ahmad, A.H., (2010). "FDI and economic growth: new evidence on the role of financial markets", Economics Letters, 107(2), 211-213.

Baltagi, B.H., (2008). Econometric analysis of panel data. New York: John Wiley \& Sons Ltd., Chichester.

Barajas, A., Gapen, M. T., Chami, R., Montiel, P., and Fullenkamp, C., (2009). "Do workers' remittances promote economic growth?", IMF Working Paper, n¹53.

Ben Mim, S., and Ben Ali, M.S., (2012). "Through Which Channels Can Remittances Spur Economic Growth in MENA Countries?", Economics: The Open-Access, OpenAssessment E-Journal, 6, 1-27.

Benhabib, J., and Spiegel, M., (2005). Human Capital and Technology Diffusion. In: Aghion, P., Durlauf, S.N. (Eds.), Handbook of Economic Growth. Elsevier, Amsterdam.

Bettin, G., and Zazzaro, A., (2012). "Remittances and financial development: Substitutes or complements in economic growth? ", Bulletin of Economic Research, 64(4), 509-536.

Blundell, R., and Bond, S., (1998). "Initial conditions and moment restrictions in dynamic panel data models", Journal of Econometrics, 87, 115-143.

Calderon, C., and Liu, L., (2003), "The direction of causality between financial development and economic growth," Journal of Development Economics, 72, 321-334.

Cao, S., and Kang, S.J., (2020). "Personal remittances and financial development for economic growth in Economic Transition
Remittances and Economic Growth in MENA Countries:

The Role of Financial Development

Countries", International Economic Journal, 34(3), 472-492.

Chami, R., Barajas, A., Cosimano, T., Fullenkamp, C., Gapen, M., and Montiel, P., (2008). "Macroeconomic consequences of remittances", IMF Occasional Paper, n²59.

Chami, R., Fullenkamp, C., and Jahjah, S., (2005). "Are immigrant remittance flows a source of capital for development?", IMF Staff Paper, 52(1), 55-81.

Chami, R., Fullenkamp, C., and Jajah, S., (2003). "Are Immigrant Remittance Flows a Source of Capital for Development?" IMF Working Paper, $n^{\circ} 189$.

Chami, R., Hakura, D.S., and Montiel, P.J., (2012). "Do worker remittances reduce output volatility in Developing Countries?" Journal of Globalization and Development, 3, 1-25.

Chowdhury, M., (2016). "Financial development, remittances and economic growth: Evidence using a dynamic panel estimation", Margin: The Journal of Applied Economic Research, 10(1), 35-54.

Coon, M., (2014). "Financial development and the end-use of migrants' remittances", Journal of Labor and Development, 3(7), 1-25.

De Haan, J., (2007). "Political institutions and economic growth reconsidered", Public Choice, 127, 281-292.

Demirguc-Kunt, A., (2006). "Finance and economic development: Policy choices for developing countries", World Bank Policy Research Working Paper, n 3955.

Dzansi, J., (2013). "Impact of remittances on domestic investment: the role of institutional and financial development", Global Review of Accounting and Finance, 4(2), 65-84.

Ekanayake, E.M., and Mihalis, H., (2008). "Do remittances and foreign direct investment promote growth? Evidence from developing countries", Journal of International Business and Economics, 8(1), 58-68. 


\section{Articles}

Ekanayake, E.M., and Moslares, C., (2020). "Do remittances promote economic growth and reduce poverty? Evidence from Latin American countries", Economies, 8(35), 1-26.

El Hamma, I., (20018). "Migrant Remittances and Economic Growth: The Role of Financial Development and Institutional Quality", Economics and Statistics, $\mathrm{n}^{\circ}$ 503-504, 123142.

Elder, J., (2004). "Another perspective on the effects of inflation uncertainty", Journal of Money, Credit, and Banking, 36, 911-928.

Fayissa, B., and Nsiah, C., (2010). "The impact of remittances on economic growth and development in Africa", The American Economist, 55(2), 92-103.

Freund, C., and Spatafora, N., (2008). "Remittances, transaction costs, and informality". Journal of Development Economics, 86(2), 356-66.

Fromentin, V., (2018). "Remittances and financial development in Latin America and the Caribbean countries: A dynamic approach", Review of DevelopmentEconomics, 22, 808-826.

Giuliano, P., and Ruiz-Arranz, M., (2009). "Remittances, financial development, and growth", Journal of Development Economics, 90, 144-152.

Gupta, P., (2005). "Macroeconomic determinants of remittances: Evidence from India," IMF Working Paper, n'224.

Gwartney, J., Lawson, R., Hall, J., and Murphy, R., (2020). Economic Freedom of the World-2020, Annual Report. Fraser Institute.

IMF, (2005). "Two current issues facing developing countries: Workers remittances and economic development", World Economic Outlook, April.

Jongwanich, J., (2007). "Workers' remittances, economic growth and poverty in developing Asia and the Pacific countries", UNESCAP Working Paper WP/07/01.
Jongwanich, J., and Kohpaiboon, A., (2019). 'Workers' remittances, capital inflows, and economic growth in developing Asia and the Pacific ", Asian Economic Journal, 33(1), 3965.

Kadozi, E., (2019). "Remittance inflows and economic growth in Rwanda", Research in Globalization, 1(100005), 1-15.

Kock, U., and Sun, Y., (2011). "Remittances in Pakistan-Why have they gone up, and why aren't they coming down?", IMF Working Papers, n²00.

Kumar, R.R., Stauvermann, P.J., Patel, A., and Prasad, S., (2018). "The Effect of remittances on economic growth in Kyrgyzstan and Macedonia: Accounting for Financial Development", International Migration, 56(1), 95-126.

Le, T., (2011). "Remittances for economic development: The investment perspective", Economic Modelling, 28, 2409-2415.

Lee, L.F., (2007). "GMM and 2SLS estimation of mixed regressive, spatial autoregressive models", Journal of Econometrics, 137, 489514.

León-Ledesma, M., and Piracha, M., (2001). "International migration and the role of remittances in Eastern Europe", Studies in Economics, 1(13), 44-80.

Levine, R., (2005). "Finance and Growth: Theory, Mechanisms and Evidence", in Aghion, P. and Durlauf, S.N. (eds.). Handbook of Economic Growth. Elsevier.

Levine, R., Loayza, N., and Beck, T., (2000). "Financial intermediation and growth: Causality and causes", Journal of Monetary Economics, 46(1), 31-77.

Lim, S., and Simmons, W.O., (2015). "Do remittances promote economic growth in the Caribbean Community and Common Market?" Journal of Economics and Business, 77, 4259. 


\section{Articles}

Lin, X., and Lee, L.F., (2010). "GMM estimation of spatial autoregressive models with unknown heteroskedasticity", Journal of Econometrics, 157, 34-52.

Mankiw, N.G., Romer., D., and Weil, D., (1992). "A contribution to the empirics of economic growth", Quarterly Journal of Economics, 107, 407-437.

Meyer, D., and Shera, A., (2017). "The impact of remittances on economic growth: An econometric model", Economia, 18(2), 147155

Misati, R.N., Kamau, A., and Nassir, H., (2019), "Do migrant remittances matter for financial development in Kenya?", Financial Innovation, 5(31), 1-25.

Mundaca, G., (2009). "Remittances, financial market development, and economic growth: The case of Latin America and the Caribbean", Review of Development Economics, 13(2), 288-303.

Nguyen, C.T., and Trinh, L.T., (2018). "The impacts of public investment on private investment and economic growth Evidence from Vietnam", Journal of Asian Business and Economic Studies, 25(1), 15-32.

Nickell, S., (1981). "Biases in dynamic models with fixed effects", Econometrica, 49, 14171426.

Nsiah, C., and Fayissa, B., (2013). "Remittances and economic growth in Africa, Asia, and Latin American-Caribbean countries: A panel unit root and panel cointegration analysis", Journal of Economics and Finance, 37, 424441.

Nyamongo, E. M., Misati, R. N., Kipyegon, L., and Ndirangu, L., (2012). "Remittances, financial development and economic growth in Africa ", Journal of Economics and Business, 64, 240-260.

Olayungbo, D. O., and Quadri, A., (2019). "Remittances, financial development and economic growth in sub-Saharan African
Remittances and Economic Growth in MENA Countries:

The Role of Financial Development

countries: evidence from a PMG-ARDL approach", Financial Innovation Journal, 5(1), $1-25$.

Ramirez, M. D., and Sharma, H., (2009). "Remittances and growth in Latin America: A panel unit root and panel cointegration analysis", Estudios Economicos de Desarrollo Internacional, 9(1), 1-33.

Ramirez, M.D., (2013). "Do financial and institutional variables enhance the impact of remittances on economic growth in Latin America and the Caribbean? A panel cointegration analysis", International Advances in Economic Research, 19, 273-288.

Ratha, D., (2007). Leveraging Remittances for Development. Migration Policy Institute. Washington D.C. World Bank.

Rempel, H., and Lobdell, R., (1978). "The role of urban-rural remittances in rural development", Journal of Development Studies, 14, 324-341.

Roodman, D., (2006). "How To Do xtabond2: An Introduction to Difference and System GMM in Stata", Center for Global Development Working Paper, $n^{\circ} 103$.

Salvador, S.L., and Ducanes, D., (2019). "Remittance, Dutch disease and manufacturing growth in developing countries", Scottish Journal of Political Economy, 66(3), 360-383.

Sobiech, I., (2019). "Remittances, finance and growth: Does financial development foster the impact of remittances on economic growth?", World Development, 113, 44-59.

Tang, Y., and Zhang, K.H., (2016). "Absorptive capacity and benefits from FDI: Evidence from Chinese manufactured exports", International Review of Economics and Finance, 42, 423-429.

Windmeijer, F., (2005). "A finite sample correction for the variance of linear efficient two-step GMM estimators", Journal of Econometrics, 126, 25-51. 
Articles

World Bank, (2020a). "Migration and Yaseen, H.S., (2012). "The positive and remittances data".

negative impact of remittances on economic

World Bank, (2020b). "Phase II: COVID-19 Crisis through a Migration Lens", Migration and Development Brief 33, October.

World Bank (2020c), World Development Indicators, World Bank, Washington DC. growth in MENA countries", Journal of International Management Studies, 7(1), 7-14.

Zghidi, N., Mohamed Sghaier, I., and Abida, Z., (2018), "Remittances, institutions, and economic growth in North African countries", Journal of the Knowledge Economy, 9,804-821. 